\title{
Novel cyclic sesquiterpene peroxides from the Formosan soft coral Sinularia sp.
}

\author{
Chih-Hua Chao, ${ }^{\text {a }}$ Chi-Hua Hsieh, ${ }^{\text {a }}$ Shin-Pin Chen, ${ }^{\text {a }}$ Chung-Kuang Lu,,${ }^{\text {bc }}$ \\ Chang-Feng Dai, ${ }^{\mathrm{d}}$ Yang-Chang $\mathrm{Wu}^{\mathrm{e}}$ and Jyh-Horng Sheu ${ }^{\mathrm{a}, *}$ \\ ${ }^{a}$ Department of Marine Biotechnology and Resources, National Sun Yat-sen University, Kaohsiung 804, Taiwan, ROC \\ ${ }^{\mathrm{b}}$ National Museum of Marine Biology and Aquarium, Checheng, Pingtung 944, Taiwan, ROC \\ ${ }^{\mathrm{c}}$ Institute of Marine Biotechnology, National Dong Hwa University, Checheng, Pingtung 944, Taiwan, ROC \\ ${ }^{\mathrm{d}}$ Institute of Oceanography, National Taiwan University, Taipei 106, Taiwan, ROC \\ ${ }^{\mathrm{e}}$ Graduate Institute of Natural Products, Kaohsiung Medical University, Kaohsiung 807, Taiwan, ROC
}

Received 30 November 2005; revised 16 January 2006; accepted 23 January 2006

\begin{abstract}
Four novel cyclic peroxide-containing sesquiterpenes (1-4), with a $\gamma$-alkylidene- $\alpha$-methyl- $\alpha, \beta$-unsaturated $\gamma$-lactone moiety, have been isolated from a Formosan soft coral of the genus Sinularia. Their structures were elucidated mainly by extensive $1 \mathrm{D}$ and 2D NMR experiments.

(C) 2006 Elsevier Ltd. All rights reserved.
\end{abstract}

Soft coral of the genus Sinularia has been found to be a rich source of bioactive secondary metabolites. ${ }^{1}$ Cyclic peroxides are of great interest because they often exhibit a wide spectrum of biological activities including antiparasitic and cytotoxic activities against cancer cells. ${ }^{2-4}$ During the course of our investigation on the bioactive chemical constituents from marine invertebrates, ${ }^{5-15}$ four novel sesquiterpenoids, sinularioperoxides A-D (1-4) possessing a cyclic peroxide and a $\gamma$-alkylidene- $\alpha$ methyl- $\alpha, \beta$-unsaturated $\gamma$-lactone moieties, have been isolated from a soft coral Sinularia sp., collected off the northeastern Taiwan coast in May 2004, at a depth of $10 \mathrm{~m}$. We describe herein the isolation and structure elucidation of these compounds.

The organism (1.0 kg fresh wt) was collected and freeze dried. The freeze-dried material was minced and extracted exhaustively with EtOH. The organic extract was concentrated to an aqueous suspension and partitioned between EtOAc and water. The EtOAc extract $(9.8 \mathrm{~g})$ was fractionated by open column chromatography on silica gel using $n$-hexane and $n$-hexane-EtOAc

\footnotetext{
Keywords: Sinularioperoxide; Sinularia; Sespuiterpene; Cyclic peroxide; Soft coral.

* Corresponding author. Tel.: +886 7 5252000x5030; fax: +886 7 5255020; e-mail: sheu@mail.nsysu.edu.tw
}

mixtures of increasing polarity. A fraction eluted with $n$-hexane/EtOAc (1:4) was subjected to Sephadex LH20 column $(2 \times 90 \mathrm{~cm})$ using acetone and followed by normal phase HPLC ( $n$-hexane/acetone, $8: 1)$ to afford compounds 1 (5.0 mg), $2(1.0 \mathrm{mg}), 3(1.1 \mathrm{mg})$, and 4 $(3.0 \mathrm{mg})$.

Sinularioperoxide (1), $[\alpha]_{\mathrm{D}}^{25}-2\left(c 1.64, \mathrm{CHCl}_{3}\right)$, was isolated as a colorless oil. Its HRESIMS exhibited a pseudomolecular ion peak at $\mathrm{m} / z 303.1209[\mathrm{M}+\mathrm{Na}]^{+}$, corresponding to the molecular formula $\mathrm{C}_{15} \mathrm{H}_{20} \mathrm{O}_{5}$ (calcd 303.1208). Thus, 1 possesses six degrees of unsaturation. The IR spectrum of $\mathbf{1}$ was found to exhibit absorptions of hydroxy $\left(3366 \mathrm{~cm}^{-1}\right)$, carbon-carbon double bond $\left(1668 \mathrm{~cm}^{-1}\right)$, and lactone carbonyl groups $\left(1757 \mathrm{~cm}^{-1}\right)$. The characteristic NMR signals $\left[\delta_{\mathrm{H}} 7.04\right.$ $(1 \mathrm{H}, \mathrm{s}, \mathrm{H}-3), 5.66(1 \mathrm{H}, \mathrm{s}, \mathrm{H}-5)$, and $2.01(3 \mathrm{H}, \mathrm{s}$, $\left.\mathrm{H}_{3}-13\right) ; \delta_{\mathrm{C}} 170.7$ (C-1), 129.1 (C-2), 138.7 (C-3), 146.2 (C-4), 117.5 (C-5), and 10.5 (C-13)] and UV absorption at $\lambda_{\max } 273 \mathrm{~nm}$ indicated the presence of $\gamma$-alkylidene- $\alpha$ methyl- $\alpha, \beta$-unsaturated $\gamma$-lactone moiety. ${ }^{16,17}$ Signals resonating at $\delta 135.4$ (s) and 127.5 (d) in ${ }^{13} \mathrm{C}$ NMR spectrum of 1 suggested the presence of a trisubstituted double bond. The above functionalities account for five of the six degrees of unsaturation in the molecule of $\mathbf{1}$, suggesting that there should be an additional ring in the molecule of sinularioperoxide A. The gross structure of metabolite 1 was further established by the 2D NMR 
studies, particularly in ${ }^{1} \mathrm{H}_{-}{ }^{1} \mathrm{H}$ COSY, HMQC, and HMBC experiments. The correlations of ${ }^{1} \mathrm{H}-{ }^{1} \mathrm{H}$ COSY revealed two spin systems, as depicted in Figure 1. Its HMBC spectrum showed many informative correlations, such as $\mathrm{H}-5$ to $\mathrm{C}-3, \mathrm{C}-4$, and $\mathrm{C}-6, \mathrm{H}_{3}-13$ to $\mathrm{C}-1, \mathrm{C}-2$, and $\mathrm{C}-3, \mathrm{H}_{3}-14$ to $\mathrm{C}-5, \mathrm{C}-6$, and $\mathrm{C}-7$; and $\mathrm{H}_{3}-15$ to $\mathrm{C}-9, \mathrm{C}-10$, and $\mathrm{C}-11$ (Fig. 1). Moreover, acetylation of 1 yielded 1a. It was found that the NMR signal of $\mathrm{H}_{2}-12$ in $\mathbf{1}$ at $\delta 4.21$ was downfield shifted to $\delta 4.61$ in 1a (Tables 1 and 2), confirming that the hydr-
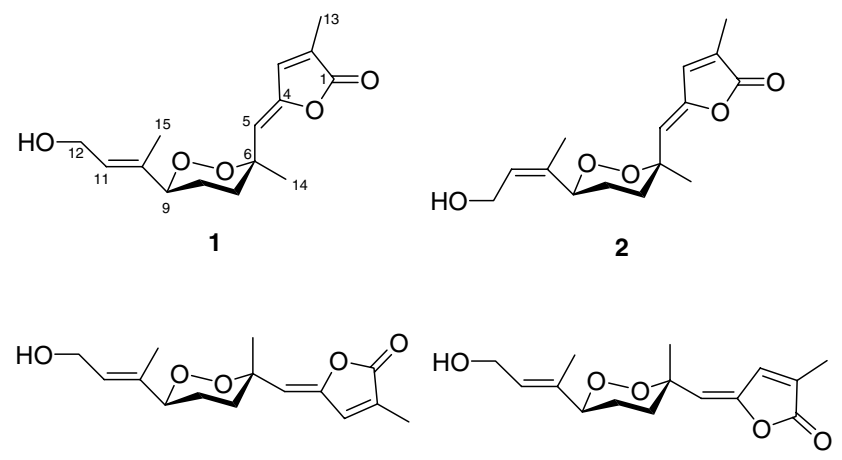

3

4

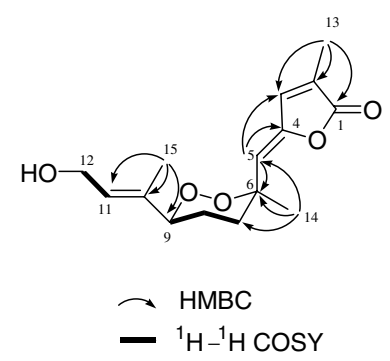

Figure 1. Selective ${ }^{1} \mathrm{H}-{ }^{1} \mathrm{H}$ COSY and HMBC correlations of $\mathbf{1}$. oxy group of 1 should be attached at C-12. From the above 2D NMR data, the molecular formula obtained from the HRESIMS, and the reductive cleavage of 1a by zinc powder and acetic acid in EtOAc to afford diol $\mathbf{1 b}^{18,19}$ (99\% yield) (Fig. 2 and Table 2) confirmed the cyclic peroxide linkage between C-6 and C-9. Combination of the above observations led to the establishment of the planar structure of $\mathbf{1}$.

The relative stereochemistry of $\mathbf{1}$ was determined by the NOE correlations observed in a NOESY experiment and also by the analysis of the coupling constant of H-9. It was found that this proton $(\delta 4.44)$ displayed a large coupling constant $(J=11.0 \mathrm{~Hz})$, revealing its axial orientation. In the NOESY spectrum of $\mathbf{1}, \mathrm{H}-9$ was found to show NOE interactions with both $\mathrm{H}-8 \alpha$ and $\mathrm{H}-7 \alpha$, and $\mathrm{H}_{3}-14$ exhibited NOE correlation with $\mathrm{H}-7 \alpha$ and $\mathrm{H}-7 \beta$. Thus, $\mathrm{H}_{3}-14$ must be equatorially oriented, and positioned on the $\alpha$ face (Fig. 3). The $E$ geometry was assigned for the 10,11-double bond on the basis of the observation of an NOE correlation between $\mathrm{H}_{3}-15$ and $\mathrm{H}_{2}-12$. The $Z$ geometry of both 2,3- and 4,5-double bonds was established by the observation of the NOE correlations of $\mathrm{H}_{3}-13 / \mathrm{H}-3$ and $\mathrm{H}-3 / \mathrm{H}-5$. Therefore, the relative structure of $\mathbf{1}$ was established unambiguously.

Compound 2, $[\alpha]_{\mathrm{D}}^{25}-40\left(c 0.80, \mathrm{CHCl}_{3}\right)$, revealing IR absorptions at 3422, 1755, and $1668 \mathrm{~cm}^{-1}$, and UV absorption $(\mathrm{MeOH})$ at $\lambda_{\max }(\log \varepsilon) 272 \mathrm{~nm}(4.19)$, was isolated as a colorless oil. Its HRESIMS exhibited a pseudomolecular ion peak at $\mathrm{m} / z 303.1206[\mathrm{M}+\mathrm{Na}]^{+}$ and established the same molecular formula as that of 1. Thus, $\mathbf{2}$ is an isomer of $\mathbf{1}$. It was found that except for $\mathrm{H}-9$, the ${ }^{1} \mathrm{H}$ NMR spectral data of $\mathbf{2}$ are very similar to those of 1 . Inspection of the ${ }^{13} \mathrm{C}$ NMR data of compounds $\mathbf{1}$ and $\mathbf{2}$ also showed obvious differences between the carbon shifts at C-9 and C-15. The carbon resonance

Table 1. ${ }^{1} \mathrm{H}$ and ${ }^{13} \mathrm{C}$ NMR spectral data of compounds $\mathbf{1}-\mathbf{4}$

\begin{tabular}{|c|c|c|c|c|c|c|c|c|}
\hline \multirow[t]{2}{*}{$\mathrm{C} \#$} & \multicolumn{2}{|l|}{1} & \multicolumn{2}{|l|}{2} & \multicolumn{2}{|l|}{3} & \multicolumn{2}{|l|}{4} \\
\hline & ${ }^{1} \mathrm{H}^{\mathrm{a}}$ & ${ }^{13} \mathrm{C}^{\mathrm{b}}$ & ${ }^{1} \mathrm{H}^{\mathrm{a}}$ & ${ }^{13} \mathrm{C}^{\mathrm{b}}$ & ${ }^{1} \mathrm{H}^{\mathrm{a}}$ & ${ }^{13} \mathrm{C}^{\mathrm{b}}$ & ${ }^{1} \mathrm{H}^{\mathrm{a}}$ & ${ }^{13} \mathrm{C}^{\mathrm{b}}$ \\
\hline 1 & & $170.7(\mathrm{~s})^{\mathrm{d}}$ & & $170.7(\mathrm{~s})$ & & $170.6(\mathrm{~s})$ & & $170.2(\mathrm{~s})$ \\
\hline 2 & & $129.1(\mathrm{~s})$ & & $129.2(\mathrm{~s})$ & & $129.6(\mathrm{~s})$ & & $131.6(\mathrm{~s})$ \\
\hline 3 & $7.04 \mathrm{~s}$ & 138.7 (d) & $7.06 \mathrm{~s}$ & $138.6(d)$ & $7.00 \mathrm{~s}$ & 138.7 (d) & $7.56 \mathrm{~s}$ & 136.8 (d) \\
\hline 4 & & $146.2(\mathrm{~s})$ & & $146.2(\mathrm{~s})$ & & $146.8(\mathrm{~s})$ & & $148.8(\mathrm{~s})$ \\
\hline 5 & $5.66 \mathrm{~s}$ & $117.5(\mathrm{~d})$ & $5.66 \mathrm{~s}$ & $117.3(\mathrm{~d})$ & $5.27 \mathrm{~s}$ & $116.4(\mathrm{~d})$ & $5.60 \mathrm{~s}$ & $115.8(\mathrm{~d})$ \\
\hline 6 & & $81.0(\mathrm{~s})$ & & $81.1(\mathrm{~s})$ & & $80.3(\mathrm{~s})$ & & $79.5(\mathrm{~s})$ \\
\hline 7 & $\begin{array}{l}\alpha 1.80 \mathrm{~m} \\
\beta 2.58 \mathrm{ddd}(13.0,3.5,3.5)^{\mathrm{c}}\end{array}$ & $34.0(\mathrm{t})$ & $\begin{array}{l}1.80 \mathrm{~m} \\
2.59 \mathrm{ddd}(12.0,3.5,3.5)\end{array}$ & $33.7(\mathrm{t})$ & $2.12 \mathrm{~m}, 2 \mathrm{H}$ & $31.6(\mathrm{t})$ & $1.92 \mathrm{~m}, 2 \mathrm{H}$ & $34.0(\mathrm{t})$ \\
\hline 8 & $\begin{array}{l}\alpha 1.70 \mathrm{~m} \\
\beta 1.75 \mathrm{~m}\end{array}$ & $25.4(\mathrm{t})$ & $\begin{array}{l}1.58 \mathrm{~m} \\
1.83 \mathrm{~m}\end{array}$ & $25.4(\mathrm{t})$ & $\begin{array}{l}1.83 \mathrm{~m} \\
1.98 \mathrm{~m}\end{array}$ & $23.1(\mathrm{t})$ & $\begin{array}{l}1.81 \mathrm{~m} \\
2.02 \mathrm{~m}\end{array}$ & $23.7(\mathrm{t})$ \\
\hline 9 & $4.44 \mathrm{~d}(11.0)$ & $84.8(\mathrm{~d})$ & $4.87 \mathrm{dd}(10.3,2.5)$ & $80.2(\mathrm{~d})$ & $4.41 \mathrm{dd}(8.0,3.5)$ & $83.8(\mathrm{~d})$ & 4.44 br d (9.5) & $84.5(\mathrm{~d})$ \\
\hline 10 & & $135.4(\mathrm{~s})$ & & $136.0(\mathrm{~s})$ & & $136.0(\mathrm{~s})$ & & $135.6(\mathrm{~s})$ \\
\hline 11 & $5.63 \mathrm{t}(6.5)$ & $127.5(\mathrm{~d})$ & $5.62 \mathrm{t}(6.5)$ & $129.7(\mathrm{~d})$ & $5.70 \mathrm{t}(6.5)$ & 126.7 (d) & $5.71 \mathrm{t}(6.5)$ & $127.3(\mathrm{~d})$ \\
\hline 12 & $4.21 \mathrm{~d}(6.5), 2 \mathrm{H}$ & $59.1(\mathrm{t})$ & $\begin{array}{l}4.16 \mathrm{dd}(12.8,6.8) \\
4.21 \mathrm{dd}(12.8,7.3)\end{array}$ & $58.5(\mathrm{t})$ & $4.25 \mathrm{~d}(6.5), 2 \mathrm{H}$ & $59.3(\mathrm{t})$ & $4.26 \mathrm{~d}(6.5), 2 \mathrm{H}$ & $59.2(\mathrm{t})$ \\
\hline 13 & $2.01 \mathrm{~s}$ & $10.5(q)$ & $2.02 \mathrm{~s}$ & $10.5(\mathrm{q})$ & $2.01 \mathrm{~s}$ & $10.5(q)$ & $2.01 \mathrm{~s}$ & $10.8(\mathrm{q})$ \\
\hline 14 & $1.41 \mathrm{~s}$ & $25.2(\mathrm{q})$ & $1.41 \mathrm{~s}$ & $25.4(\mathrm{q})$ & $1.57 \mathrm{~s}$ & $22.6(q)$ & $1.56 \mathrm{~s}$ & $24.0(\mathrm{q})$ \\
\hline 15 & $1.68 \mathrm{~s}$ & $14.0(\mathrm{q})$ & $1.69 \mathrm{~s}$ & $19.5(\mathrm{q})$ & $1.75 \mathrm{~s}$ & $13.8(\mathrm{q})$ & $1.75 \mathrm{~s}$ & $13.7(\mathrm{q})$ \\
\hline
\end{tabular}

\footnotetext{
${ }^{\text {a }}$ Spectra recorded at $500 \mathrm{MHz}$ in $\mathrm{CDCl}_{3}$ at $25^{\circ} \mathrm{C}$.

${ }^{\text {b }}$ Spectra recorded at $125 \mathrm{MHz}$ in $\mathrm{CDCl}_{3}$ at $25^{\circ} \mathrm{C}$.

${ }^{\mathrm{c}} J$ values (in $\mathrm{Hz}$ ) in parentheses.

${ }^{\mathrm{d}}$ Multiplicity deduced by DEPT and indicated by usual symbols.
} 
Table 2. ${ }^{1} \mathrm{H}$ and ${ }^{13} \mathrm{C}$ NMR chemical shifts of derivatives $\mathbf{1 a}$ and $\mathbf{1 b}$

\begin{tabular}{|c|c|c|c|c|}
\hline \multirow[t]{2}{*}{$\mathrm{C} \#$} & \multicolumn{2}{|l|}{ la } & \multicolumn{2}{|c|}{$1 \mathbf{b}$} \\
\hline & ${ }^{1} \mathrm{H}^{\mathrm{a}}$ & ${ }^{13} \mathrm{C}^{\mathrm{b}}$ & ${ }^{1} \mathrm{H}^{\mathrm{c}}$ & ${ }^{13} \mathrm{C}^{\mathrm{d}}$ \\
\hline 1 & & $170.7 \mathrm{~s}^{\mathrm{f}}$ & & $170.3 \mathrm{~s}$ \\
\hline 2 & & $129.1 \mathrm{~s}$ & & $129.0 \mathrm{~s}$ \\
\hline 3 & $7.05 \mathrm{~s}$ & $138.7 \mathrm{~d}$ & $6.99 \mathrm{~s}$ & $138.6 \mathrm{~d}$ \\
\hline 4 & & $146.2 \mathrm{~s}$ & & $146.3 \mathrm{~s}$ \\
\hline 5 & $5.66 \mathrm{~s}$ & $117.4 \mathrm{~d}$ & $5.25 \mathrm{~s}$ & $120.0 \mathrm{~d}$ \\
\hline 6 & & $81.0 \mathrm{~s}$ & & $72.8 \mathrm{~s}$ \\
\hline \multirow[t]{2}{*}{7} & $1.80 \mathrm{~m}$ & $34.0 \mathrm{t}$ & $1.80 \mathrm{~m}$ & $39.1 \mathrm{t}$ \\
\hline & 2.60 br d $(10.7)^{\mathrm{e}}$ & & $1.90 \mathrm{~m}$ & \\
\hline \multirow[t]{2}{*}{8} & $1.70 \mathrm{~m}$ & $25.5 \mathrm{t}$ & $1.67 \mathrm{~m}$ & $29.7 \mathrm{t}$ \\
\hline & $1.75 \mathrm{~m}$ & & $1.30 \mathrm{~m}$ & \\
\hline 9 & 4.45 br d (7.5) & $84.5 \mathrm{~d}$ & $4.05 \mathrm{t}(6.2)$ & $77.3 \mathrm{~d}$ \\
\hline 10 & & $137.7 \mathrm{~s}$ & & $143.0 \mathrm{~s}$ \\
\hline 11 & $5.54 \mathrm{t}(6.2)$ & $122.3 \mathrm{~d}$ & $5.59 \mathrm{t}(6.5)$ & $119.6 \mathrm{~d}$ \\
\hline 12 & $4.61 \mathrm{~d}(6.8)$ & $60.7 \mathrm{t}$ & $4.62 \mathrm{~d}(6.8)$ & $60.9 \mathrm{t}$ \\
\hline 13 & $2.02 \mathrm{~s}$ & $10.4 \mathrm{q}$ & $2.00 \mathrm{~s}$ & $10.5 \mathrm{q}$ \\
\hline 14 & $1.41 \mathrm{~s}$ & $25.2 \mathrm{q}$ & $1.48 \mathrm{~s}$ & $29.0 \mathrm{q}$ \\
\hline 15 & $1.71 \mathrm{~s}$ & $14.0 \mathrm{q}$ & $1.68 \mathrm{~s}$ & $12.3 \mathrm{q}$ \\
\hline \multirow[t]{2}{*}{ OAc } & $2.06 \mathrm{~s}$ & $20.9 \mathrm{q}$ & $2.06 \mathrm{~s}$ & $21.0 \mathrm{q}$ \\
\hline & & $170.9 \mathrm{~s}$ & & $171.0 \mathrm{~s}$ \\
\hline
\end{tabular}

${ }^{\text {a }}$ Spectra recorded at $300 \mathrm{MHz}$ in $\mathrm{CDCl}_{3}$ at $25^{\circ} \mathrm{C}$.

${ }^{\text {b }}$ Spectra recorded at $75 \mathrm{MHz}$ in $\mathrm{CDCl}_{3}$ at $25^{\circ} \mathrm{C}$.

${ }^{\mathrm{c}}$ Spectra recorded at $400 \mathrm{MHz}$ in $\mathrm{CDCl}_{3}$ at $25^{\circ} \mathrm{C}$.

${ }^{\mathrm{d}}$ Spectra recorded at $100 \mathrm{MHz}$ in $\mathrm{CDCl}_{3}$ at $25^{\circ} \mathrm{C}$.

${ }^{\mathrm{e}} J$ values (in $\mathrm{Hz}$ ) in parentheses.

${ }^{\mathrm{f}}$ Multiplicity deduced by DEPT and indicated by usual symbols.

of C-9 at $\delta 84.8$ in 1 was found to be upfield shifted to $\delta$ 80.2 in 2, while that of C-15 at $\delta 14.0$ in 1 was shifted to lower field ( $\delta$ 19.5) in 2 (Table 1). The above differences may be due to the $E$ geometry of 10,11-double bond in $\mathbf{1}$ has been converted to $Z$ geometry in 2 . Those findings were further confirmed by an NOE correlation between $\mathrm{H}_{3}-15$ and $\mathrm{H}-11$ (Fig. 3). This phenomenon can be explained by the significant $\gamma$-effect ${ }^{20,21}$ arising from the steric compression between $11-\mathrm{CH}_{2} \mathrm{OH}$ and $\mathrm{C}-15$ in 1 and $11-\mathrm{CH}_{2} \mathrm{OH}$ and $\mathrm{C}-9$ in 2. After detailed examination of $1 \mathrm{D}$ and $2 \mathrm{D} \mathrm{NMR}$, the structure of $\mathbf{2}$ was established and named as sinularioperoxide $\mathrm{B}$.

Sinularioperoxide $\mathrm{C}(3),[\alpha]_{\mathrm{D}}^{25}-2\left(c 1.68, \mathrm{CHCl}_{3}\right)$, was isolated as a colorless oil. The molecular formula 3 was determined by HRESIMS and was found to be identical to that of 1 . The IR $\left(v_{\max } 3366,1755\right.$, and $\left.1672 \mathrm{~cm}^{-1}\right)$ and UV $\left(\lambda_{\max } 272 \mathrm{~nm}\right)$ spectral data of 3 are almost the same as those of $\mathbf{1}$. Thus, $\mathbf{3}$ is the geometric isomer of both $\mathbf{1}$ and $\mathbf{2}$. By comparison of the NMR data of $\mathbf{3}$ with those of $\mathbf{1}$, the obvious differences were observed for chemical shifts of C-14 ( $\delta 22.6$ in 3 and 25.2 in 1), H-5 ( $\delta 5.27$ in 3 and 5.66 in 1), and H-7 $(\delta$
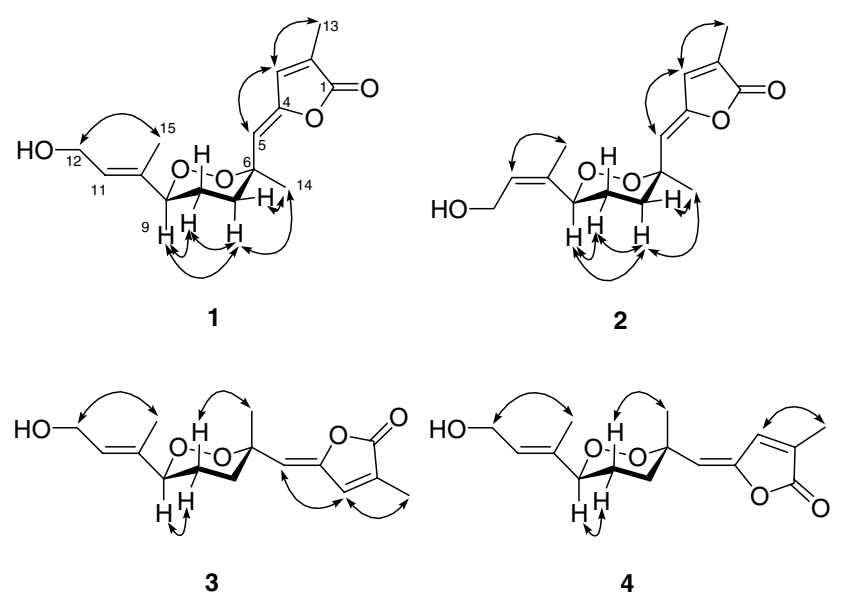

Figure 3. Selective NOESY correlations of $\mathbf{1 - 4}$.

2.12, $2 \mathrm{H}$, in 3 and 1.80 and 2.58 in 1) (Table 1). These findings suggested that the equatorial methyl $\mathrm{H}_{3}-14$ in 1 might be converted to the axial orientation in 3 . The above findings were further confirmed by the detailed inspection of the NOESY spectrum, which showed NOE correlations of $\mathrm{H}-9 / \mathrm{H}-8 \alpha$ and $\mathrm{H}-8 \beta / \mathrm{H}_{3}-14$ (Fig. 3). Thus, the molecular structure of $\mathbf{3}$, including the relative configuration, was fully determined.

HRESIMS of sinularioperoxide D (4), appeared as a colorless oil with an $[\alpha]_{\mathrm{D}}^{25}$ value of $-2\left(c 1.68, \mathrm{CHCl}_{3}\right)$, exhibited a pseudomolecular ion peak at $\mathrm{m} / \mathrm{z} 303.1206$ $[\mathrm{M}+\mathrm{Na}]^{+}$and established the same molecular formula as those of 1-3. The IR and UV spectra of 4 showed absorptions at 3418, 1766, and $1666 \mathrm{~cm}^{-1}$ and $273 \mathrm{~nm}$, respectively. By comparison of the ${ }^{1} \mathrm{H}$ and ${ }^{13} \mathrm{C} N M R$ spectra of $\mathbf{3}$ and $\mathbf{4}$, these two compounds have very similar spectral data except for the deviation between proton signals of $\mathrm{H}-5$ in $3(\delta 5.27)$ and 4 ( $\delta$ 5.60) (Table 1). The NOESY spectra of $\mathbf{3}$ and $\mathbf{4}$ were also similar except for the lack of an NOE correlation between H-3 and $\mathrm{H}-5$ in 4 (Fig. 3). Therefore, 4 should contain an $E$ double bond between C-4 and C-5 and the structure of this metabolite was determined unambiguously.

Preliminary biological activity screening revealed that these four compounds are not active against the growth of a limited panel of cancer cell lines, including A549 (human lung carcinoma), HepG2 (human hepatocellular carcinoma), MCF7 and MAD-MB-231 (both human breast carcinoma) cells. The results of further biological activity screening will be reported elsewhere in the future.

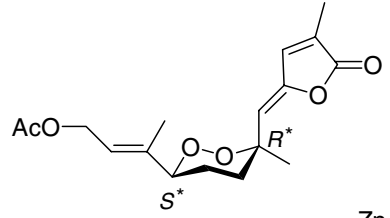

$1 \mathbf{a}$

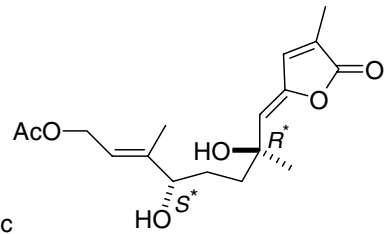

$1 b$

Figure 2. Conversion of $\mathbf{1 a}$ to diol $\mathbf{1 b}$. 
It has to be noted here that cyclic peroxides 1-4 are the brand-new type of cyclic peroxy terpenoids with a $\gamma$ alkylidene- $\alpha$-methyl- $\alpha, \beta$-unsaturated $\gamma$-lactone moiety. To the best of our knowledge, this type of terpenoids was discovered for the first time.

\section{Acknowledgments}

Financial support of this work provided by Ministry of Education and National Science Council of Taiwan awarded to J.-H.S. is greatly appreciated.

\section{References and notes}

1. Blunt, J. W.; Copp, B. R.; Munro, M. H. G.; Northcote, P. T.; Prinsep, M. R. Nat. Prod. Rep. 2005, 22, 15-61, and references cited therein.

2. Compagnone, R. S.; Pina, I. C.; Rangel, H. R.; Dagger, F.; Suarez, A. I.; Rami, R. M. V.; Faulkner, D. J. Tetrahedron 1998, 54, 3057-3068.

3. Casteel, D. A. Nat. Prod. Rep. 1999, 16, 55-73.

4. Fattorusso, E.; Parapini, S.; Campagnuolo, C.; Basilico, N.; Taglialatela-Scafati, O.; Taramelli, D. J. Antimicrob. Chemother. 2002, 50, 883-888.

5. Wu, S.-L.; Sung, P.-J.; Su, J.-H.; Sheu, J.-H. J. Nat. Prod. 2003, 66, 1252-1256.

6. Sheu, J.-H.; Huang, L.-F.; Chen, S.-P.; Yang, Y.-L.; Sung, P.-J.; Wang, G.-H.; Su, J.-H.; Chao, C.-H.; Hu, W.-P.; Wang, J.-J. J. Nat. Prod. 2003, 66, 917-921.

7. Sheu, J.-H.; Wang, G.-H.; Duh, C.-Y.; Soong, K. J. Nat. Prod. 2003, 66, 662-666.
8. Ahmed, A. F.; Su, J.-H.; Shiue, R.-T.; Pan, X.-J.; Dai, C.-F.; Kuo, Y.-H.; Sheu, J.-H. J. Nat. Prod. 2004, 67, 592597.

9. Ahmed, A. F.; Su, J.-H.; Kuo, Y.-H.; Sheu, J.-H. J. Nat. Prod. 2004, 67, 2079-2082.

10. Chao, C.-H.; Huang, L.-F.; Yang, Y.-L.; Su, J.-H.; Wang, G.-H.; Chiang, M. Y.; Wu, Y.-C.; Dai, C.-F.; Sheu, J.-H. J. Nat. Prod. 2005, 68, 880-885.

11. Ahmed, A. F.; Wu, M.-H.; Wang, G.-H.; Wu, Y.-C.; Sheu, J.-H. J. Nat. Prod. 2005, 68, 1051-1055.

12. Tseng, Y.-J.; Ahmed, A. F.; Dai, C.-F.; Chiang, M. Y.; Sheu, J.-H. Org. Lett. 2005, 7, 3813-3816.

13. Wang, G.-H.; Sheu, J.-H.; Chiang, M. Y.; Lee, T.-J. Tetrahedron Lett. 2001, 42, 2333-2336.

14. Sheu, J.-H.; Chen, S.-P.; Sung, P.-J.; Chiang, M. Y.; Dai, C.-F. Tetrahedron Lett. 2000, 41, 7885-7888.

15. Sheu, J.-H.; Chao, C.-H.; Wang, G.-H.; Hung, K.-C.; Duh, C.-Y.; Chiang, M. Y.; Wu, Y.-C.; Wu, C.-C. Tetrahedron Lett. 2004, 45, 6413-6416.

16. Takayama, H.; Ichikawa, T.; Kuwajim, T.; Kitajima, M.; Seki, H.; Aimi, N.; Nonata, M. G. J. Am. Chem. Soc. 2000, 122, 8635-8639.

17. Takayama, H.; Ichikawa, T.; Kitajima, M.; Aimi, N.; Lopez, D.; Nonata, M. G. Tetrahedron Lett. 2001, 42, 2995-2996.

18. Uchio, Y.; Eguchi, S.; Kuramoto, J.; Nakayama, M.; Hase, T. Tetrahedron Lett. 1985, 26, 4487-4490.

19. Phuwapraisirisan, P.; Matsunaga, S.; Fusetani, N.; Chaitanawisuti, N.; Kritsanapuntu, S.; Menasveta, P. J. Nat. Prod. 2003, 66, 289-291.

20. Lambert, J. B.; Shurvell, H. F.; Lightner, D. A.; Cooks, R. G. Organic Structure Spectroscopy; Prentice-Hall: USA, 1998; pp 49-52.

21. Wang, G.-H.; Ahmed, A. F.; Sheu, J.-H.; Duh, C.-Y.; Shen, Y.-C.; Wang, L.-T. J. Nat. Prod. 2002, 65, 887-891. 